\title{
Effects of sponge and barnacle encrustation on survival of the scallop Chlamys hastata
}

\author{
Heather M. Farren · Deborah A. Donovan
}

Received: 26 July 2006/Revised: 15 April 2007 / Accepted: 30 April 2007 / Published online: 5 July 2007

(C) Springer Science+Business Media B.V. 2007

\begin{abstract}
The scallop Chlamys hastata frequently carries epibionts such as sponges and barnacles on its shells. Although the scallop-sponge relationship has been characterized as a mutualism, little is known about the scallop-barnacle relationship. This study investigated the effects of sponge and barnacle encrustation on the ability of $C$. hastata to avoid predation by the sea star Pycnopodia helianthoides. In feeding trials, $P$. helianthoides caught and consumed significantly more barnacle-encrusted scallops ( $7.7 \pm 0.8$ out of 20 scallops $)$ than scallops encrusted by either of the sponges Myxilla incrustans $(4.1 \pm 0.9)$ or Mycale adhaerens $(3.0 \pm 0.5)$. Epibiont-free scallops $(5.7 \pm 0.5)$ formed an intermediate treatment between barnacle-encrusted and sponge-encrusted scallops. Possible mechanisms by which the sponges protected the scallops were investigated in two ways: two feeding trials were videotaped to allow qualitative analysis of sea star and scallop behavior and sea star feeding responses to scallop and sponge homogenates were determined to investigate if sea stars accept scallops and sponges as prey. Sea stars displayed positive feeding
\end{abstract}

Handling editor: K. Martens

H. M. Farren · D. A. Donovan $(\varangle)$

Department of Biology, MS 9160, Western

Washington University, 516 High St, Bellingham,

WA 98225, USA

e-mail: donovan@biol.wwu.edu responses to scallop puree $97.5 \% \pm 1.6$ of the time while only displaying positive responses to Mycale adhaerens homogenate $4.4 \% \pm 2.0$ of the time and to Myxilla incrustans homogenate $4.4 \% \pm 2.9$ of the time. The videotaped feeding trials indicated that interference with tube feet adhesion by the sponge deterred predation. Observations of both sea stars that were videotaped showed that neither avoided trying to capture sponge-encrusted scallops, and at no time was a captured scallop willingly released by the sea stars. Thus, it appears that sponges provide tactile-mechanical protection and possibly chemical or tactile camouflage in this predator/prey relationship. Finally, the effects of sponge encrustation on barnacle settlement were determined. Field experiments showed that barnacle larvae settled more frequently on epibiont-free scallops than on those with either of the two sponges, potentially protecting the scallops from an epibiont that increases the scallop's susceptibility to predation.

Keywords Scallop - Sea star - Epibiont . Predator-prey interactions · Associational resistance $\cdot$ Share-doom

\section{Introduction}

Interactions involving bivalve molluscs and their predators can be mediated by epibionts encrusting the bivalve's shells. Since the shell surface 
provides cues (e.g. tactile or chemical) for the predator regarding prey acceptability, any change in the surface can alter the outcome of a predator's response. Epibionts can reduce prey susceptibility by providing an unpalatable or camouflaged exterior for the prey ("associational resistance") or they can increase susceptibility if they themselves are a preferred prey item for the predator ("shared doom") (Wahl \& Hay, 1995; Wahl et al., 1997; Laudien \& Wahl, 1999). It is also possible for an epibiont to influence escape mechanisms of bivalves, thereby changing the probability that they will escape predation (Bloom, 1975; Forester, 1979; Chernoff, 1987; Pitcher \& Butler, 1987; Pond, 1992; Donovan et al., 2002, 2003). Thus, the type of epibiont found on shells of bivalves can determine whether a predator is likely to consume the bivalve or not.

The scallop Chlamys hastata Sowerby frequently carries epibionts on its shells including sponges, barnacles, tubeworms, bryozoans, tunicates, and algae (Lescinsky, 1993). In the waters of the San Juan Islands, Washington, USA, the type of epibiont found on these scallops varies with habitat (Lescinsky, 1993; D.A. Donovan, personal observations). In some places, nearly all the scallops are covered by sponge, while in other places many scallops have barnacles attached to them or are epibiont-free. The mechanisms driving this variability are unknown. In general though, sponge-encrusted scallops are seemingly more abundant than scallops with barnacle epibionts, suggesting either that barnacle larvae do not settle on scallop shells very often or that scallop mortality increases when barnacles are attached to them.

The relationship between $C$. hastata and its epibiotic sponges Mycale adhaerens Lambe and Myxilla incrustans Esper is generally considered a mutualism. Bloom (1975) found that the sponges protect $C$. hastata from sea star predation by providing tactile camouflage and preventing tube foot adhesion during escape swimming, while the motility of the scallop protects the sponge from nudibranch predators. Donovan et al. (2002) determined that sponge encrustation does not significantly affect the scallop's ability to swim and concluded that the benefits of escaping predation were not offset by harm to other biological functions that require swimming. Burns \& Bingham (2002) found that this scallop-sponge relationship also benefits the sponge because sponge survival is increased due to the prevention of sediment accumulation. Both $M$. adhaerens and $M$. incrustans have a low tolerance for sediment and spontaneous clapping or swimming by the scallop cleared the sponges of sediment, increasing survival. The scallop-sponge association is not limited to C. hastata and M. adhaerens/ $M$. incrustans and has been documented in several species around the world, usually with the conclusion that the relationship is beneficial to both organisms (Forester, 1979; Chernoff, 1987; Pitcher \& Butler, 1987; Pond, 1992).

While there is evidence that sponge encrustation protects scallops from sea star predation, the mechanism by which this occurs may have multiple components. Sponges disrupt tubefeet adhesion such that the scallop is more likely to escape by swimming away since the sea star can't grip the scallop as effectively (Bloom, 1975; Forester, 1979; Pitcher \& Butler, 1987). However, sponge encrustation may also tactilely or chemically camouflage scallops from predators by altering the exterior of the scallop so it is not as readily identified as a prey item. This has been demonstrated in sessile bivalves such as mussels, clams, and oysters which can be less susceptible to predation if they are encrusted by epibionts that are unpalatable to the predator or that make the bivalve less conspicuous (Vance, 1978; Feifarek, 1987; Wahl et al., 1997; Laudien \& Wahl, 1999). Sponges also possess chemical defenses to deter their own predators, including sea stars (Waddell \& Pawlik, 2000; McClintock et al., 2005), and by encrusting a scallop they may make the scallop less palatable to a sea star predator.

Although the scallop-sponge relationship has been investigated in a number of different species, less is known about the relationships between scallops and their other epibionts. Scallops in the San Juan Islands sometimes carry barnacles on their shells, including several species of balanoid barnacles (Lescinsky, 1993). Increased mass and drag caused by barnacles reduces the ability of scallops to swim, causing a decrease in swimming height, time, and distance compared to unencrusted scallops (Donovan et al., 2003). This presumably makes 
scallops more vulnerable to predation since they are less able to swim out of a sea star's reach. However, it is also possible that barnacles are unpalatable to sea stars thus providing associational resistance to the scallop. For example, the sea star Pycnopodia helianthoides ingests scallops by engulfing them whole. In a previous study, Donovan et al. (1999) found that $P$. helianthoides prefers smooth prey such as the snail Nucella lamellosa compared to prey with protruding varices such as the snail Ceratostoma foliatum. Thus, barnacles could potentially protect scallops from $P$. helianthoides if they interfere with or deter ingestion.

This study sought to determine the consequences of epibiotic sponges, Mycale adhaerens and Myxilla incrustans, and epibiotic balanoid barnacles on the survival of the scallop Chlamys hastata and to further explore the scallop-sponge and scallop-barnacle relationships. Three questions were asked: (1) Do different epibionts (sponges and barnacles) have different effects on scallop survival when the scallops are confronted with a sea star predator? (2) Do homogenates of sponge tissues elicit positive or negative feeding responses from sea stars, especially when compared with homogenates of scallop tissues? and (3) Does the presence of a sponge on a scallop prevent settlement by barnacles, which are potentially detrimental?

\section{Materials and methods}

\section{Experimental animals}

Scallops (Chlamys hastata) were collected by SCUBA near Shannon Point Marine Center (SPMC), Anacortes, WA. They were held at SPMC in sea tables with a constant supply of running seawater at ambient temperature (8$\left.11^{\circ} \mathrm{C}\right)$ and salinity $(32 \%)$. The seawater was not filtered, which allowed the scallops to feed.

The scallops were separated into four groups according to their dominant epibiont: (1) epibiontfree (less than $5 \%$ epibiont coverage, with no barnacles), (2) Mycale adhaerens-encrusted (more than $70 \%$ of the left valve covered by sponge, with no barnacles), (3) Myxilla incrustans-encrusted (more than $70 \%$ of the left valve covered by sponge, with no barnacles), and (4) barnacleencrusted (scallops with one or more large balanoid barnacles on their shells, either Balanus nubilus or Balanus rostratus, or several small Balanus glandula). Scallops with barnacles often had other epibionts such as bryozoans and tunicates so all other epibionts were removed prior to using the barnacle-encrusted scallops to ensure that any observed effects were due to the barnacles. As well, the few epibionts sometimes found on the "epibiont-free" scallops were removed. Very few sponge-encrusted scallops carried other epibionts. If there were other large epibionts that could not be removed without interfering with the sponge encrustation, the scallop was not used.

Pycnopodia helianthoides was used as the sea star predator since it is known to feed on a variety of marine bivalves (Mauzey et al., 1968) and it elicits a dramatic escape response from $C$. hastata indicating it probably feeds on these scallops in the field. Pycnopodia helianthoides uses chemoreception to locate prey (Breen, 1979; Brewer \& Konar, 2005) and displays behavioral responses to food typical of other sea stars (Valentincic, 1983; Brewer \& Konar, 2005). The sea stars were collected by SCUBA near SPMC and were kept in sea tables with a constant supply of fresh seawater at ambient temperature and salinity. They were fed mussels ad libitum. Prior to the feeding trials, the sea stars were housed separately for one week during which time they were starved to ensure that all previously consumed food had been digested and any shells had been egested. A period of one week was chosen based on descriptions of $P$. helianthoides feeding behavior (Mauzey et al., 1968) and on observations of the sea stars prior to experimentation.

Feeding preference of sea stars

To determine if epibiont type affects the number of scallops caught and consumed by $P$. helianthoides, sea stars $(N=9 ; 13-33 \mathrm{~cm}$ radius from center of oral disc to arm tip) were presented with a constant selection of scallops. Individual $P$. helianthoides were placed in a flow-through sea table ( $1.5 \mathrm{~m}$ long, $0.6 \mathrm{~m}$ wide, $0.3 \mathrm{~m}$ deep) with eight scallops including two of each epibiont type: epibiont-free, Mycale adhaerens-encrusted, 
Myxilla incrustans-encrusted, and barnacle-encrusted. Initially, the scallops were all placed at one end of the sea table while the sea star was placed at the opposite end. The sea stars and scallops were monitored every $24 \mathrm{~h}$ and when a scallop was consumed during the $24 \mathrm{~h}$ period, another scallop of the same epibiont type was added and the empty shells were removed. Each trial lasted until each $P$. helianthoides had consumed and discarded the empty shells of 20 scallops, approximately 20-30 days. In total, 68 epibiont-free scallops $(5.6 \pm 0.01 \mathrm{~cm}$ shell height; all values represent mean $\pm \mathrm{SE}$ unless otherwise noted), 50 Mycale adhaerens-encrusted scallops $(6.3 \pm 0.01 \mathrm{~cm}), 68$ Myxilla incrustans-encrusted scallops $(5.7 \pm 0.01 \mathrm{~cm})$, and 90 barnacle-encrusted scallops $(5.9 \pm 0.01 \mathrm{~cm})$ were offered to sea stars in this experiment.

To gain further insight into the feeding behavior of $P$. helianthoides, two of the nine trials were videotaped using a camera suspended above the sea table. Time lapse was used, with two frames per minute.

There is a substantial literature addressing the problem of statistical analysis of feeding preference data in which an individual predator is presented with several food choices and the selection of one prey item is not independent of the selection of other prey items (Peterson \& Renaud, 1989; Roa, 1992; Manly, 1993). The Quade test can be used to analyze experiments in which the food choices are not independent, there are no autogenic changes over the duration of the experiment (Peterson \& Renaud, 1989; Roa, 1992), and the blocks (trials with individual sea stars) are independent (Quade, 1979; Conover, 1999). Essentially, the Quade test is a two-way ANOVA on ranks (Roa, 1992; Conover, 1999) and a multiple comparison test can be used when significant differences are found (Roa 1992; Conover, 1999).

Sea star response to scallop and sponge homogenates

To investigate whether tissues from scallops and epibiotic sponges elicit feeding behaviors in $P$. helianthoides, sea stars were offered strips of filter paper soaked in homogenates of whole scallop tissue or whole sponge tissue. Many sea stars display typical reactions when presented with substances perceived as food. A positive response is indicated by arm-curling and tube-feet extension (Valentincic, 1983; Brewer \& Konar, 2005; Kidawa, 2005) while a negative response is indicated by tube-feet retraction (McClintock et al., 1994, 2000).

Homogenates of scallop tissue and tissue from each of the sponges were prepared. Scallop homogenate was made by removing all the soft tissues from one scallop (approximately 8-10 g) and homogenizing them in $125 \mathrm{ml}$ fresh seawater. Mycale adhaerens and Myxilla incrustans homogenates were made by homogenizing all of the sponge from one heavily encrusted scallop (approximately 5-7 $\mathrm{g}$ of each sponge) in separate $125 \mathrm{ml}$ aliquots of seawater. Thus, the homogenates represented the amount of scallop and sponge tissues found on one sponge-encrusted scallop. All tissues were homogenized in a tabletop blender for $1 \mathrm{~min}$ and the homogenates were poured into individual $600 \mathrm{ml}$ beakers which were placed on ice to prevent degradation. The homogenates were allowed to settle for approximately $45 \mathrm{~min}$ then strained to remove pieces of tissue. Strips of filter paper $(2.5 \mathrm{~cm})$ were used to absorb the homogenates. Each strip was soaked in a homogenate for $2 \mathrm{~min}$ before it was offered to $P$. helianthoides. The blender was thoroughly cleaned between each homogenate.

At the beginning of the experiment, Pycnopodia helianthoides $(N=8 ; 19-26 \mathrm{~cm}$ radius $)$ were placed individually into scrubbed seawater tables and allowed to settle in the tank for $2 \mathrm{~h}$ before the start of a trial. Each sea star was then offered the three treatments 20 times each, for a total of 60 offerings over an approximately $5 \mathrm{~h}$ period, so a percentage acceptance for each homogenate could be determined. A random number table was used to assign the order in which the homogenates were offered. Pieces of treated filter paper were offered to a sea star by holding the paper $1 \mathrm{~cm}$ from the sensory tube feet at the tip of an extended arm. Typically, the sea star extended the tube feet at the end of its arms toward the filter paper, then exhibited either a positive or negative response. A positive response consisted of grabbing the filter paper with the tube feet and moving the filter paper 
along its arm and toward its mouth (after Valentincic, 1983). A negative response consisted of releasing the filter paper by retracting its tube-feet and moving its arms away from the paper. Since every sea star demonstrated a clear response within $60 \mathrm{~s}$, each response was scored as either positive or negative. Each sea star had a rest period of 3-5 min between offerings and there was no sign of fatigue on the part of the sea stars.

Percent acceptance data were arc-sine transformed before being analyzed using a one-way repeated measures ANOVA since the assumption of sphericity was met. This was followed by a Tukey's post hoc comparison.

\section{Barnacle settlement on scallops}

To determine the effect of sponge encrustation on barnacle settlement, epibiont-free, Mycale adhaerens-encrusted and Myxilla incrustans-encrusted scallops were monitored for barnacle encrustation over a 3 month period. Twenty cages, each containing three scallops (one of each treatment), were suspended in the water at Anacortes Marina in Anacortes, WA during spring 2003 when barnacle cyprids would be present. Cages were attached to a polypropylene line, which was woven through the cages to maintain position and avoid loss or slippage of the cages. Because of space constraints, five lines were used to suspend five cages each: four scallop cages and a bottom cage weighted with rocks. Thus, the cages containing scallops were placed at four depths. Cable ties were used to reinforce the door hinges.

Each of the cages with scallops contained one epibiont-free scallop, one Mycale adhaerens-encrusted scallop, and one Myxilla incrustans-encrusted scallop. All sponge-encrusted scallops initially had at least $80 \%$ sponge cover on the left valve and at least partial (10-50\%) cover on the right valve. The cages were monitored every 3-4 weeks for scallop mortality, indicated by empty shells, and two dead scallops were removed from analysis.

After 3 months, the scallops were removed from the cages and transported to Shannon Point Marine Center. A digital photograph was taken of both valves of each scallop and a diagram was made showing the amount and location of each epibiont. Final percent sponge cover was estimated for both valves and the total number of barnacles on each valve was counted.

Mean numbers of barnacles on the left valves of the scallops were analyzed by ANOVA with epibiont type as the main effect. Additionally, the number of barnacles on each valve was regressed against the final percent sponge cover on both right and left valves.

\section{Results}

Feeding preference of sea stars

Pycnopodia helianthoides captured and consumed more barnacle-encrusted scallops (mean of $7.7 \pm 0.8$ out of 20 scallops consumed) than either of the sponge-encrusted scallops $(4.1 \pm 0.9$ for $M$. incrustans and $3.0 \pm 0.5$ for M. adhaerens; Fig. 1). Epibiont-free scallops $(5.7 \pm 0.5)$ were intermediate to the barnacle-encrusted and spongeencrusted treatments. Analysis of the ranked preferences among the sea stars indicated that these differences were statistically significant ( $T=5.69, P<0.001$; Quade's test). A post-hoc multiple comparison test (Conover, 1999) showed that the barnacle-encrusted scallops were consumed significantly more often than both sponge-encrusted treatments. The epibiont-free

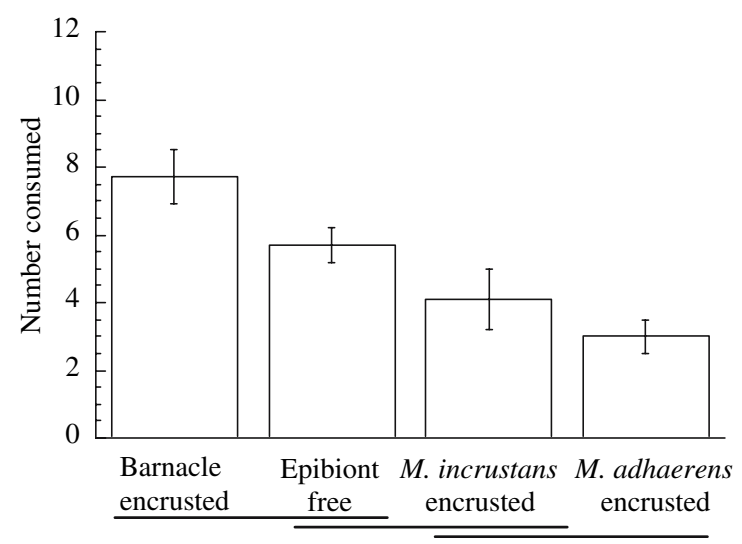

Fig. 1 Mean number of scallops (out of 20 consumed) with different epibionts captured and consumed by the sea star Pycnopodia helianthoides $(N=9)$. Error bars represent standard error. Bars under the epibiont types represent homogenous subgroups as determined by an analysis of the ranked preferences of the sea stars (Quade test) followed by a multiple comparison test 
treatment and the barnacle-encrusted treatment formed a homogenous subgroup, as did the epibiont-free treatment and the Myxilla incrustans-encrusted treatment. The two sponge encrusted treatments also formed a homogeneous subgroup (Fig. 1).

It is possible that the walls of the sea table impeded the swimming of the scallops, facilitating their capture by sea stars. However, this effect would be most detrimental to the best swimmers [i.e. sponge-encrusted and epibiont-free scallops; Donovan et al. (2002, 2003)]. Thus, it is possible that our results underestimate the differences in mortality between barnacle-encrusted scallops and those with other epibionts.

Sea star response to scallop and sponge homogenates

There was a significant difference in the percent acceptance of the three homogenates. Pycnopodia helianthoides accepted scallop homogenate $97.5 \% \pm 1.6$ of the time, while only accepting Mycale adhaerens homogenate $4.4 \% \pm 2.0$ of the time and Myxilla incrustans homogenate $4.4 \% \pm 2.9$ of the time (Fig. 2). Post-hoc comparisons (Tukey's) indicated that scallop homogenate was accepted significantly more often than the two sponge homogenates $(P<0.001$ for both $)$, and that the two sponge homogenates were not significantly different from each other.

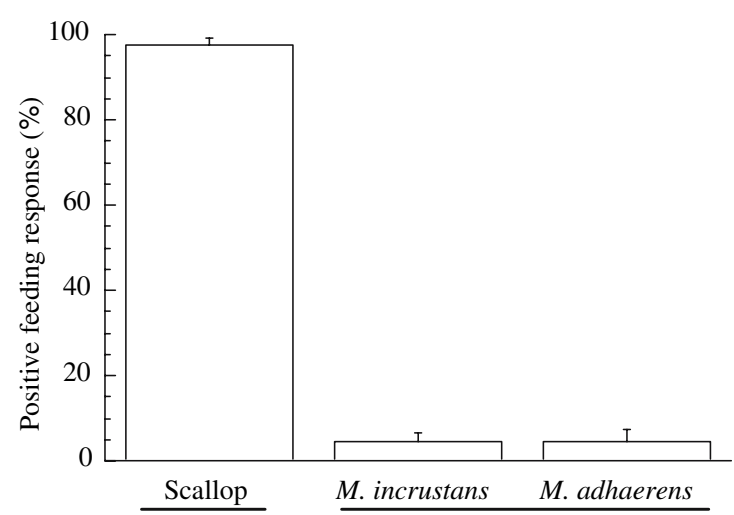

Fig. 2 Mean positive feeding responses displayed by Pycnopodia helianthoides $(N=8)$ to scallop and sponge homogenates. Error bars represent standard error. Bars under the treatment types represent homogeneous subgroups determined by repeated measures ANOVA and Tukey post-hoc comparisons
Barnacle encrustation of scallops

Epibiont type had a significant effect on the number of barnacles encrusted on the left valve of scallops after 3 months in the field $\left(F_{2,54}=12.5\right.$, $P<0.001$; Fig. 3). Barnacles were found on epibiont-free scallops significantly more often than on scallops encrusted with either of the two sponges $(P<0.001$ for $M$. adhaerens and $P=0.014$ for $M$. incrustans, Tukey's test), although there was no statistical difference between the numbers of barnacles found on scallops with the two sponge types $(P=0.11)$.

Scallops with greater sponge cover tended to have fewer barnacles encrusted on their valves. The number of barnacles that settled on the valves of the scallops was inversely related to the final percent sponge cover on that valve $\left(r^{2}=0.22\right.$, $t=11.0, P=0.002$ for $M$. adhaerens; $r^{2}=0.42$, $t=25.5, P<0.001$ for $M$. incrustans; Fig. 4).

The barnacles that settled on the scallops were Balanus crenatus.

\section{Discussion}

It is evident that different epibionts found on the scallop Chlamys hastata mediate predator-prey interactions between the scallop and its sea star predator Pycnopodia helianthoides in different

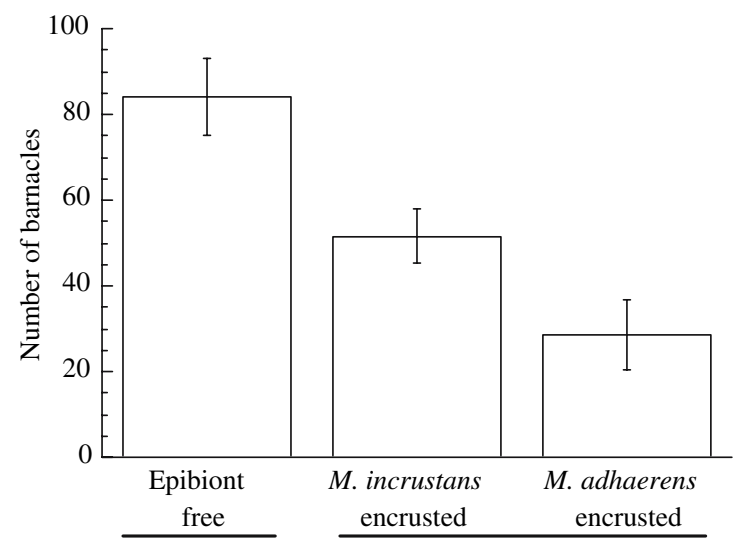

Fig. 3 Mean numbers of barnacles encrusted on the left valves of scallops with different epibiont types after 3 months caged in the field. Error bars represent standard error. Bars under the treatment types represent homogenous subgroups determined by ANOVA and Tukey posthoc comparisons 


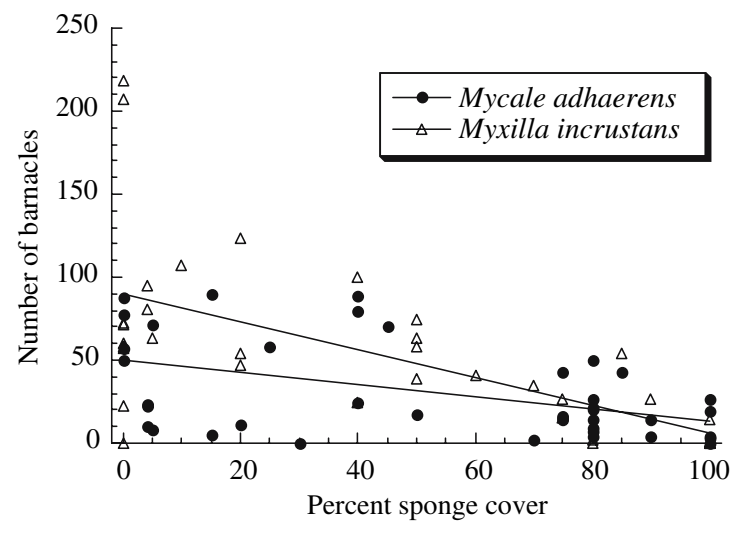

Fig. 4 Regressions of number of barnacles against final percent sponge cover on both valves of scallops encrusted with Mycale adhaerens and Myxilla incrustans. Regression equations were: number of barnacles $=50-0.37$ (percent sponge cover), $r^{2}=0.22, t=11.0, P=0.002$ for $M$. adhaerens and number of barnacles $=89-0.83$ (percent sponge cover), $r^{2}=0.42, t=25.5, P<0.001$ for $M$. incrustans

ways. In this context, sponges confer "associational resistance" (e.g. Wahl \& Hay, 1995; Wahl et al., 1997) since sponge encrustation decreased the likelihood that sea stars caught and consumed scallops. Associational resistance occurs when an epibiont decreases predation on its host due to the alteration of the host's exterior such that it is not consumed as readily by the predator. Associational resistance can be conferred in a variety of ways including chemical defense, chemical or tactile camouflage, or tactile-mechanical protection (Laudien \& Wahl, 2004).

In the case of $C$. hastata, there appears to be a combination of effects. The feeding trials with the homogenates suggest that $P$. helianthoides does not identify sponge as a prey item, although it is unclear from our study whether this is due to chemical defense or lack of nutritional value on the part of the sponge. As such, the sponge could be conferring chemical or tactile camouflage. However, the videotapes from the feeding trials indicated that interference with tube feet adhesion also deterred predation. The behavioral trends identified in these videos showed that both sea stars detected scallops from a distance and the sea star subsequently moved rapidly toward the scallops. However, there was no evidence that either sea star targeted scallops with a particular epibiont. Typically, its leading arms would contact the closest scallop and, if the scallop swam away and the capture attempt failed, the sea star pursued the next closest scallop. Once a sea star captured a scallop, it would engulf the scallop and remain relatively quiet during digestion. After digestion, it released the empty shell and pursued more scallops. Thus, both sea stars that were videotaped did not avoid trying to capture sponge-encrusted scallops, and at no time was a captured scallop willingly released by the sea stars. Instead, the spongeencrusted scallops were more likely to escape during sea star attacks. This is consistent with Bloom's (1975) conclusion that sponge encrustation provides tactile camouflage and decreases the force needed for $C$. hastata to escape the grip of the sea star's tube feet.

In contrast, Laudien \& Wahl (2004) found that epibiont chemical deterrence, rather than structural/mechanical properties, was the primary mechanism protecting blue mussels from predation by Asterias rubens. This could reflect a difference in the motile vs. sessile lifestyles of scallops compared to mussels. The effects of epibionts have been elucidated for other sessile bivalve species and their sea star predators, usually with the conclusion that the epibionts conferred chemical defense or camouflage. Vance (1978) found that the cemented clam Chama pellucida was less susceptible to detection and predation by Pisaster giganteus when it was encrusted by a variety of organisms including algae, sponges, hydroids, bryozoans, and tunicates, probably due to camouflage of the clam by organisms less palatable to the sea star. As well, the sea star Asterias rubens significantly preferred epibiont-free mussels over those with barnacles, red algae, sponge or hydrozoans, although barnacle-encrusted mussels were the second most preferred prey (Laudien \& Wahl, 1999). Finally, Feifarek (1987) found that sponge encrustation provided optical and chemical camouflage for the oyster Spondylus americanus. Chlamys hastata, however, has the ability to swim out of the reach of $P$. helianthoides and can thus mount an effective motile escape from this predator. Thus, tactile-mechanical protection may work particularly well for scallops compared to their sedentary relatives. Tactile-mechanical protection has also 
been demonstrated for the mobile sea urchin Sterechinus neumayeri (Amsler et al., 1999). In this case, the urchin carries macroalgae on its test as cover and releases it if the urchin wanders into contact with tentacles of the predatory anemone Isotealia antarctica. The macroalgae impedes the ability of the anemone to grasp the urchin and the urchin is able to quickly crawl away, leaving the algae behind. However, mechanical defenses may also be effective for sessile bivalves, especially if the epibiont interferes with the sea star's ability to pry open the bivalve as has been suggested for the protection conferred by the slipper limpet Crepidula fornicata to the mussel Mytilus edulis (Thieltges, 2005).

In comparison to sponge encrustation, barnacle encrustation can be seen as a case of "shared doom" since predation risk increased for scallops with one or more large barnacles. The mechanism by which this occurs is different than those previously described in the literature however (see Laudien \& Wahl, 2004). Shared doom often occurs when an epibiont attracts predators either optically or chemically, making predation on its host more likely. In the case of $C$. hastata, barnacles were not necessarily sought by the sea star as prey, rather they hindered the ability of the scallop to escape predation and thus they were both consumed. Barnacles compromise scallop swimming by decreasing the time and distance that a scallop is able to swim, by decreasing the height in the water column the scallop is able to attain, and by increasing the drag coefficient of the scallop (Donovan et al., 2003). Scallops also need to maintain a minimum swimming speed to stay in the water column (Cheng \& Demont, 1996) and barnacles, if of sufficient size and/or number, may prevent this causing the scallop not to be able to swim at all. Indeed, some of the scallops in our study carried barnacles so large the scallop was no longer capable of swimming. Whether barnacles increase the susceptibility of scallops to sea star predation in the field is unknown, but this is likely given our laboratory results and the scarcity of barnacle-encrusted scallops compared to sponge-encrusted scallops. The hypothesis that barnacle encrustation increases scallop mortality is supported by Lescinsky (1993) who found that live scallops dredged from Puget Sound had fewer barnacles on either left or right valves compared to dead scallops (shells) dredged from the same location. In this case, scallops collected while alive had an average of $13 \%$ of their left valve area covered by barnacles while shells collected from dead scallops averaged $23 \%$ of their left valve area.

In our experiment, barnacles readily settled on the caged scallops, further indicating that the scarcity of barnacle-encrusted scallops in the San Juan archipelago may be due to increased mortality rather than a failure of barnacles to settle on scallops. However, sponge encrustation protected scallops from barnacle settlement. When caged in the field for 3 months, epibiont-free scallops had significantly more barnacles growing on their left valves than scallops encrusted with either of the two sponge types. Furthermore, the number of barnacles found on the scallop valves was inversely related to the final percentage of the valve that was covered by sponge. Inspection of the scallop shells revealed that the barnacles settled on bare patches of shell between sponge cover. This deterrence of barnacle settlement could be physical or chemical, or a combination of the two, although this was not investigated in our study. Barnacle larvae prefer rough surfaces with grooves and concavities (Lewis, 1978), and tend to settle on fine or medium textured surfaces rather than completely smooth surfaces (Hills \& Thomason, 1998). As sponge grows on a scallop, it alters the surface of the shell forming a surface that may no longer be an attractive substratum to barnacle larvae. Marine sponges also contain antifouling compounds that deter settlement of organisms such as barnacles, mussels and ascidians (Sears et al., 1990; Willemsen, 1994; Tsukamoto et al., 1997; Armstrong et al., 1999).

In conclusion, sponge and barnacle epibionts affected the outcome of predator-prey interactions between Chlamys hastata and Pycnopodia helianthoides in different ways. Both sponges conferred associational resistance by decreasing the risk of predation for the scallop. This protection was likely due to mechanical-tactile interference and possibly tactile or chemical camouflage from the sponge. On the contrary, barnacle encrustation increased the probability that $C$. hastata was caught and consumed by $P$. helianthoides in a case 
of shared doom by interfering with the scallop's swimming escape. Furthermore, sponge encrustation deterred barnacle settlement. Thus, sponge encrustation protects scallops from both predation and detrimental epibionts, strengthening the description of this scallop-sponge association as a mutualism.

Acknowledgements We wish to thank the faculty and staff at Shannon Point Marine Center for research space and support, and the Anacortes Marina for providing dock space for the field experiment. Brian Bingham, Gene McKeen, Giséle Muller-Parker, and Nathan Schwarck helped immensely with scallop collection. Sandra Caldwell and Patrick Gloman assisted with data collection. The barnacles that settled on the caged scallops were identified by Dr. William Newman at Scripps Oceanographic Institute. Dr. Tom Carefoot, Dr. James McClintock, and an anonymous reviewer provided helpful feedback on various drafts of the manuscript.

\section{References}

Amsler, C. D., J. B. McClintock \& B. J. Baker, 1999. An Antarctic feeding triangle: defensive interactions between macroalgae, sea urchins, and sea anemones. Marine Ecology Progress Series 183: 105-114.

Armstrong, E., J. D. McKenzie \& G. T. Goldsworthy, 1999. Aquaculture of sponges on scallops for natural products research and antifouling. Journal of Biotechnology 70: 163-174.

Bloom, S. A., 1975. The motile escape response of a sessile prey: a sponge-scallop mutualism. Journal of Experimental Marine Biology and Ecology 17: 311-321.

Breen, P. A., 1979. Selective feeding of the sunflower star, Pycnopodia helianthoides, in the laboratory. Fisheries and Marine Service Manuscript Report 1498: 10 pp.

Brewer, R. \& B. Konar, 2005. Chemosensory responses and foraging behavior of the seastar Pycnopodia helianthoides. Marine Biology 147: 789-795.

Burns, D. O. \& B. L. Bingham, 2002. Epibiotic sponges on the scallops Chlamys hastata and Chlamys rubida: increased survival in a high-sediment environment. Journal of the Marine Biological Association of the United Kingdom 82: 4098-4104.

Cheng J. Y. \& M. E. DeMont, 1996. Jet-propelled swimming in scallops: swimming mechanics and ontogenic scaling. Canadian Journal of Zoology 74: 1734-1748.

Chernoff, H., 1987. Factors affecting the mortality of the scallop Chlamys asperrima (Lamark) and its epizoic sponges in south Australian waters. Journal of Experimental Marine Biology and Ecology 109: 155171.

Conover, W. J., 1999. Practical Nonparametric Statistics, 3rd edn. Wiley and Sons, NY.

Donovan, D. A., J. P. Danko \& T. H. Carefoot, 1999. Functional significance of shell sculpture in gastropod molluscs: test of a predator-deterrent hypothesis in Ceratostoma foliatum (Gmelin). Journal of Experimental Marine Biology and Ecology 236: 235-251.

Donovan, D. A., B. L. Bingham, H. M. Farren, R. Gallardo \& V. Vigilant, 2002. The effect of sponge encrustation on the swimming behavior, energetics, and morphometry of the scallop Chlamys hastata (Sowerby). Journal of the Marine Biological Association of the United Kingdom 82: 469-476.

Donovan, D. A., B. L. Bingham, M. From, A. F. Fleisch \& E. S. Loomis, 2003. Effects of barnacle encrustation on the swimming behaviour, energetics, morphometry and drag of the scallop Chlamys hastata. Journal of the Marine Biological Association of the United Kingdom 83: 813-819.

Feifarek, B. P., 1987. Spines and epibionts as antipredator defense in the thorny oyster Spondylus americanus Herman. Journal of Experimental Marine Biology and Ecology 105: 39-56.

Forester, A. J., 1979. The association between the sponge Halichondria panacea (Pallas) and scallop Chlamys varia (L.): a commensal-protective mutualism. Journal of Experimental Marine Biology and Ecology 36: $1-10$.

Hills, J. M. \& J. C. Thomason, 1998. The effect of scales of surface roughness on the settlement of barnacle (Semibalanus balanoides) cyprids. Biofouling 12: 5769.

Kidawa, A., 2005. Behavioural and metabolic responses of the Antarctic sea star Odontaster validus to food stimuli of different concentration. Polar Biology 28: 449-455.

Laudien, J. \& M. Wahl, 1999. Indirect effects of epibiosis on host mortality: Seastar predation on differently fouled mussels. Marine Ecology 20: 35-47.

Laudien, J. \& M. Wahl, 2004. Associational resistance of fouled blue mussels (Mytilus edulis) against starfish (Asterias rubens) predation: relative importance of structural and chemical properties of the epibionts. Helgoland Marine Research 58: 162-167.

Lescinsky, H. L., 1993. Taphonomy and paleoecology of epibionts on the scallops Chlamys hastata (Sowerby 1843) and Chlamys rubida (Hinds 1845). Palaios 8: 267-277.

Lewis, C. A., 1978. A review of substratum selection in free-living and symbiotic Cirripeds. In Chia, F.-S. \& M. E. Rice (eds.) Settlement and Metamorphosis of Marine Invertebrate Larvae. Elsevier, New York: 207-218.

Manly, B. F. J., 1993. Comments on design and analysis of multiple-choice feeding preference experiments. Oecologia 93: 149-152.

Mauzey, K. P., C. Birkeland \& P. K. Dayton, 1968. Feeding behavior of asteroids and escape responses of their prey in the Puget Sound region. Ecology 49: 603619.

McClintock, J. B., B. J. Baker, M. Slattery, M. Hamann, R. Koptizke \& J. Heine, 1994. Chemotactic tube-foot responses of a spongivorous sea star Perknaster fuscus to organic extracts from Antarctic sponges. Journal of Chemical Ecology 20: 859-870. 
McClintock, J. B., B. J. Baker, C. D. Amsler \& T. L. Barlow, 2000. Chemotactic tube-foot responses of the spongivorous sea star Perknaster fuscus to organic extracts of sponges from McMurdo Sound, Antarctica. Antarctic Science 12: 41-46.

McClintock, J. B., C. D. Amsler, B. J. Baker \& R. W. van Soest, 2005. Ecology of Antarctic sponges: an overview. Integrative and Comparative Biology 45: 359368.

Peterson, C. H. \& P. E. Renaud, 1989. Analysis of feeding preference experiments. Oecologia 80: 82-86.

Pitcher, C. R. \& A. J. Butler, 1987. Predation by asteroids, escape response, and morphometrics of scallops with epizoic sponges. Journal of Experimental Marine Biology and Ecology 112: 233-249.

Pond, D., 1992. Protective-commensal mutualism between the queen scallop Chlamys opercularis (Linnaeus) and the encrusting sponge Suberites. Journal of Molluscan Studies 58: 127-134.

Quade, D., 1979. Using weighted rankings in the analysis of complete blocks with additive block effects. Journal of the American Statistics Association 74: 680-683.

Roa, R., 1992. Design and analysis of multiple-choice feeding preference experiments. Oecologia 89: 509515.

Sears, M. A., D. J. Gerhart \& D. Rittschof, 1990. Antifouling agents from marine sponge Lissodendoryx isodictyalis Carter. Journal of Chemical Ecology 16: 791-799.
Thieltges, D. W., 2005. Benefit from an invader: American slipper limpet Crepidula fornicata reduces star fish predation on basibiont European mussels. Hydrobiologia 541: 241-244.

Tsukamoto, S., H. Kato, H. Hirota \& N. Fusetani, 1997. Antifouling terpenes and steroids against barnacle larvae from marine sponges. Biofouling 11: 283-291.

Valentincic, T., 1983. Innate and learned responses to external stimuli in Asteroids. In Jangoux, M. \& J. M Lawrence (eds.), Echinoderm Studies, vol. 1. Balkema, Rotterdam: 111-138.

Waddell, B. \& J. R. Pawlik, 2000. Defenses of Caribbean sponges against invertebrate predators. II. Assays with sea stars. Marine Ecology Progress Series 195: 133-144.

Wahl, M. \& M. E. Hay, 1995. Associational resistance and shared doom: effects of epibiosis on herbivory. Oecologia 102: 329-340.

Wahl, M., M. E. Hay \& P. Enderline, 1997. Effects of epibiosis on consumer-prey interactions. Hydrobiologia 355: 49-59.

Willemsen, P. R., 1994. The screening of sponge extracts for antifouling activity using a bioassay with laboratory-reared cyprids larvae of the barnacle Balanus amphitrite. International Biodeterioration and Biodegradation 34: 361-373. 